\title{
The Biopsychosocial Sphere of Women Victims of Violence: A Systematic Review
}

\section{ABSTRACT}

Objective: Identify the contribution of developed research to a biopsychosocial sphere of women victims of violence and the meaning attributed to these experiences in their lives. Method: An integrative review conducted in MEDLINE/PubMed and LILACS databases, covering the years from 2009 to 2015. Results: We selected and analyzed 18 studies with the selection criteria being the reasons given by women for remaining with a violent partner, the reasons for not seeking help to break the cycle of violence, or the meaning attributed to this experience in their lives, including the social, religious, ethical and moral meaning, as well as the suffering derived from the experience. Discussion: Interventions at health institutions allow for the development of strategies for coping with this issue. A complaint lodged by the wife against her attacker demonstrates an early break in the cycle of violence. Conclusion: The results evidence aspects that can help to improve the quality of health among these women and show the importance of research to support practices in caring for women who are victims of violence.

\section{KEYWORDS}

Violence against women; intimate partner violence domestic violence; nursing care; social representation (Source: DeCS, BIREME).

\section{DOI: 10.5294/aqui.2017.17.4.3}

Para citar este artículo / To reference this article / Para citar este artigo

Pereira-da Silva F, Pereira-de Oliveira FA, Varela S, Batista RA, Rodrigues-Barbosa L. The Biopsychosocial Sphere of Women Victims of Violence: A Systematic Review. 2017; 17(4): 390-400. Doi: 10.5294/aqui.2017.17.4.3

1 Orcid.org/0000-0002-6453-2407. Faculdade Anhanguera de Guarulhos. Brazil. fagpsilva@haoc.com.br

2 Orcid.org/0000-0001-5083-807X. Faculdade Anhanguera de Guarulhos. Brazil. fabiodeoliveira.binho@aedu.com

3 Orcid.org/0000-0002-1049-9226. Faculdade Anhanguera de Guarulhos. Brazil.samara.varela@aedu.com

4 Orcid.org/0000-0002-2657-0058. Faculdade Anhanguera de Guarulhos. Brazil. regiane.batista@aedu.com

5 Orcid.org/0000-0002-8065-8210. Faculdade Anhanguera de Guarulhos. Brazil. lucienebarbosa@anhanguera.com
Recibido: 18 de enero de 2016 Enviado a pares: 30 de enero de 2016 Aceptado por pares: 04 de noviembre de 2016 Aprobado: 03 de marzo de 2017 


\section{La esfera biopsicosocial de las mujeres víctimas de la vĩolencia: una revisión sïstemátíca}

\section{RESUMEN}

Objetivo: Identificar la contribución de la investigación desarrollada a una esfera biopsicosocial de mujeres víctimas de violencia y el significado atribuido a estas experiencias en sus vidas. Método: Revisión integradora realizada en los bases de datos MEDLINE / PubMed y LILACS, que cubre los años de 2009 a 2015. Resultados: Se seleccionaron y analizaron 18 estudios, con los criterios de selección siendo las razones dadas por las mujeres para permanecer con un compañero violento, las razones para no buscar ayuda para romper el ciclo de violencia o el significado atribuido a esta experiencia en sus vidas, incluyendo el significado religioso, ético y moral, así como el sufrimiento derivado de la experiencia. Discusión: Las intervenciones llevadas a cabo en las instituciones de salud permiten el desarrollo de estratificaciones para hacer frente a este problema. Una denuncia presentada por una esposa contra su atacante demuestra una ruptura temprana en el ciclo de violencia. Conclusión: Los resultados evidencian aspectos que pueden ayudar a mejorar la calidad de la salud de estas mujeres y muestran la importancia de la investigación para apoyar las prácticas en el cuidado de las mujeres víctimas de la violencia.

\section{PALABRAS CLAVE}

Violencia contra la mujer; violencia de pareja; violencia doméstica; cuidado de enfermería; representación social (Fuente: DeCS, BIREME). 


\section{A esfera biopsicossocial de mulheres vítimas de violência: uma revisão sistemática}

\section{RESUMO}

Objetivo: identificar a contribuição de pesquisas desenvolvidas na esfera biopsicossocial de mulheres vítimas de violência e o significado atribuído a essas experiências em suas vidas. Materiais e método: revisão integrativa conduzida nas bases de dados MEDLINE/ PubMed e LILACS, abrangendo os anos desde 2009 até 2015. Resultados: selecionamos e analisamos 18 trabalhos com os critérios de seleção: os motivos dados pelas mulheres para ficar com um parceiro violento, os motivos por não procurarem ajuda para quebrar o ciclo de violência ou o significado atribuído a essa experiência em suas vidas, incluindo o significado social, religioso, ético e moral, como também o sofrimento derivado da experiência. Discussão: intervenções em instituições de saúde permitem o desenvolvimento de estratégias para lidar com esse assunto. A denúncia da esposa contra seu atacante demonstra uma quebra precoce no ciclo de violência. Conclusões: os resultados evidenciam aspectos que podem ajudar a melhorar a qualidade da saúde de mulheres que são vítimas de violência e mostrar a importância da pesquisa para apoiar práticas de cuidados para elas.

\section{PALAVRAS-CHAVE}

Cuidado de enfermagem; representação social; violência contra as mulheres; violência doméstica; violência provocada por parceiro íntimo (Fonte: DeCS, BIREME). 


\section{Introduction}

Violence is understood by the World Health Organization as the intentional use of physical force or power, real or threatened, against oneself, against another person, or against a group or community that either results in or has a possibility of resulting in injury, death, psychological harm, developmental disability or deprivation (1).

Nowadays, violence against women is a target of concern for public health in Brazil and worldwide (2, 3), since many are victims of violence within the family and, in most situations, that violence is perpetrated by someone they live with every day $(2,4,5)$.

The number of cases involving women who are victims of aggression but fail to take any decision due to fear and/or lack of information is significant (5). This problem tends to affect the nuclear family and causes a disruption in its organization $(6,7)$.

According to one study, 1.5 to 5.3 million women per year report having been physically or sexually victimized by their male partners at some time in their life (8).

The so-called "Maria da Penha" Law, enacted in 2006 in Brazil, defines physical violence as any action that jeopardizes a woman's integrity or physical health, being characterized as any action, omission or suffering of a sexual, physical, psychological and bodily, property or moral nature that occurs within the family or home. The same law defines moral violence as an action that involves injury, defamation or libel. It defines psychological violence as any action that causes emotional damage or decreased self-esteem and well-being. Finally, it defines sexual violence as any action that causes embarrassment and the performance of sexual intercourse without consent or through coercion and/or physical strength (9).

Domestic violence has been the subject of many studies around the world, both for its various forms of expression and for the consequences for those involved. It is regarded as a transgenerational and interactional phenomenon (10).

Following a study conducted by the Pan American Health Organization in collaboration with the US Centers for Disease Control (CDC), a report was produced that highlights sexual violence against women as being widespread throughout Latin America and the Caribbean, which is where the survey data was collected. It is noteworthy that between $17 \%$ and $53 \%$ of the women interviewed reported having suffered physical or sexual violence perpetrated by an intimate partner (11).

The intervention of health services plays a fundamental role for women in situations of violence and ensures their human rights, given that most of these victims have contact with some type of health service at some point, even for reasons other than those related to aggression. This contact is necessary to identify violence and requires maximum attention from health professionals (12).

One study found that a significant number of health professionals believe issues related to violence are closely linked to the field of justice and security, and they are fearful of getting involved with issues or even calls of this nature (13). It is also observed that some health professionals who provide assistance to victims of violence are not adequately prepared for this type of care and experience a psychic discomfort due to the feelings of powerlessness and frustration that are generated during such care (14).

Thus, in order to subsidize the reflection on violence suffered by women, we decided to conduct this study aimed at identifying the contribution of developed research to a biopsychosocial sphere of women victims of violence and the meaning attributed to these experiences in their lives.

\section{Method}

An exploratory study was done, featuring a systematic review conducted through a critical analysis of the articles. A rigorous review was planned to summarize original research, highlighting the relevant research questions. A clear method was used to identify, select, describe the quality, collect data and analyze the studies.

The research began by asking a guiding question: "What literature has brought about social representations of women victims of violence?"

National and international databases were used to search and select the articles: LILACS (Latin American Center and Information Caribbean Health Sciences) and Pubmed (Public Medline). These articles were published between the year 2009 and June 2015. 


\section{Instrument for a systematic review}

The methodological tool used in the evaluation of scientific papers was PRISMA (15). It was used for the systematic review, so as to ensure quality and make this type of study clear (16).

\section{Identification and classification}

Inclusion and exclusion criteria were established to select the articles. These criteria certify the accuracy and reliability of the study.

\section{Eligibility}

The selection was determined by reading the articles obtained by two reviewers, who performed a rigorous analysis based on pre-established inclusion criteria (Table 1).

Table 1. Literary style search

\begin{tabular}{|c|c|}
\hline Literary search & $\begin{array}{l}\text { Selection for inclusion } \\
\text { based on the title }\end{array}$ \\
\hline LILACS, MEDLINE/ PubMed & \multirow{3}{*}{$\begin{array}{l}\text { - Violence } \\
\text { - Woman } \\
\text { - Nursing } \\
\text { - Denunciation of violence }\end{array}$} \\
\hline Selection Criteria & \\
\hline $\begin{array}{l}\text { - Published between } 2009 \\
\text { and June } 2017 \\
\text { - In English } \\
\text { - MeSH and DeCS: nursing } \\
\text { care, violence against } \\
\text { women and gender } \\
\text { violence }\end{array}$ & \\
\hline \multicolumn{2}{|c|}{$\begin{array}{l}\text { Selection for inclusion based on abstract } \\
\text { and stage and eligibility }\end{array}$} \\
\hline $\begin{array}{l}\text { Inclusion: } \\
\text { - Explanation of articles } \\
\text { relating to violence against } \\
\text { women } \\
\text { - Available in full and free of } \\
\text { charge } \\
\text { - Related to the study goals }\end{array}$ & $\begin{array}{l}\text { Exclusion: } \\
\text { - Incomplete articles } \\
\text { - Outside of the established } \\
\text { publication year } \\
\text { - Opinion articles, letters to } \\
\text { the editor and dissertations }\end{array}$ \\
\hline
\end{tabular}

Source: Own elaboration.

\section{Results}

The selection of articles in the first filter turned up 66 in LILACS (Latin American Center and Information Caribbean Health Sciences), 42 in PubMed (Public Medline), and 74 in Medline (Medical Literature Analysis and Retrieval System Online). Articles that do not fit the theme, are not available full, and are outside the established publication period were excluded. In all, there were 164 . After reading and analyzing the articles, 18 remained (Figure 1).

Figure 1. Flowchart of articles selected for analysis

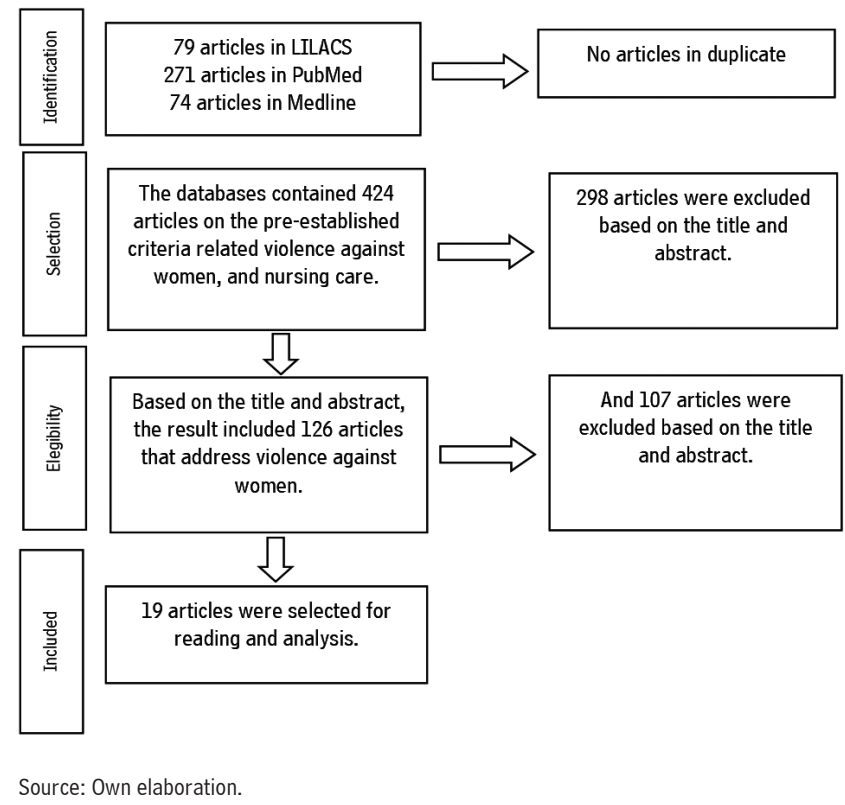

An analysis of the 19 selected studies showed that four of them used a quantitative approach, thirteen used a qualitative approach, and one study used a quantitative/qualitative approach. Among the studies with a qualitative approach, one used the phenomenological theoretical framework developed by Alfred Schütz.

The most frequent descriptors were: Domestic violence/ Violence against Women/Intimate partner violence/Women's health. As for data collection, semi-structured questionnaires were used in nine studies and structured interviews in three. There were two focus groups, while two studies used the Conflict 
Tactics Scale and the Multi-country Study on Women's Health and Life Experiences Questionnaire, both of which are validated instruments. One study based data collection on an interview.

In terms of age groups, the respondents were between 15 and 72 years old. Six of the studies addressed only domestic violence; five addressed domestic violence; four dealt with physical and psychological violence, and three focused on sexual violence. Table 2 shows some of the data analyzed.

As to the objectives set out by the authors of the selected studies, one of the prime ones is the concern to seek scientific answers to everyday issues that permeate the difficulty and the current challenges in health to serving these women. Thus, some studies have sought to identify what motivates women to not report their abusers, with a focus on different angles; namely, through a reflection on the biopsychosocial aspects involved, the context in which cases of violence occur, the reasons that lead women to file a complaint, and even the perceptions of health professionals who serve these women.

The results of this review were classified into two categories: meanings of the experience of violence endured by women and reasons to break the cycle of violence.

Meanings of the experience of violence endured by women: Out of the 18 studies selected for this review, twelve contemplated the question of the meaning of the experience of violence endured by women, whether in the household or in the care of a health service $(12,17)$. Feelings of uncertainty, fear and submission were noted, and some women reported increased anxiety, insecurity, a greater number of nightmares, and feelings of panic (18). Violence against women is felt by them as cultural privatization and symbolic; one laid the blame on those who fail to do anything. Other no less worrying feelings, though on a smaller scale, also involved socio-political and health actions, namely: anger, pain, shame, feelings of anguish and abandonment, low self-esteem, helplessness, grief, desire to break off the relationship with the partner, depression, sadness, loneliness, and suicidal thoughts, among others $(5,7)$. To be treated at the hospital has added a sense of embarrassment to the problem these women face, a feeling of discomfort at needing to present their case (17).
The denial and lack of comprehensive care perceived by women are often the result of professionals who are unprepared to deal with their own values and beliefs on the subject. This can trigger many feelings that will reflect on or impact the meaning women who have been raped will give to this experience. The service providedinvolves technicalities that prevent a humanized approach, specifically one that seeks sensitive listening and a dialogue between user and professional in search of a close relationship to establish trust for adequate care (14-21).

Recognition of disorganization in customer service is evidenced as one of the impediments to developing the provision of assistance, as was the difficulty in identifying and treating the silence victims displayed during consultation, so as to confirm suspicions of violence (13)

Reasons related to perpetuation or a break in the cycle of violence. The most cited are socioeconomic factors (unemployment or fear of losing their jobs); domestic violence (sexual, physical and psychological coercion perpetrated by intimate partners and family); the difficulty in accessing services to file a complaint; fear of death; fear of the family or fear of disappointing the family; and the desire not to abandon the children and their home. In relation to breaking the cycle of violence, the women identified despair at changes in the offender's behavior; a desire for freedom and control of one's own life; and a yearning for a definitive separation from their companion, among other less cited reasons.

When asked about the forms of psychological aggression suffered, the most cited were: insults, verbal threats and intimidating looks, and external communication deprivation, either through verbal or electronic means $(3,5,22)$.

Psychological abuse was identified as a factor triggering physical aggression, because it usually is the primary act of an individual who intends to offend a woman.

In terms of physical violence, types of aggression such as slaps, kicks and jerks, intentional burns, use of a weapon or fire and property damage are the most common means adopted by the aggressor $(3,5)$. There are also sexual violence situations where the woman is forced to have sex with her partner against her will or to perform unconventional sex acts $(5,22,23)$. 
Table 2. Description of the studies included in the review for analysis

\begin{tabular}{|c|c|c|c|c|}
\hline References & Aims & Theoretical reference & Subjects & $\begin{array}{l}\text { Instrument for data } \\
\text { collection }\end{array}$ \\
\hline $\begin{array}{l}\text { Nascimento et } \\
\quad \text { al. (13) }\end{array}$ & $\begin{array}{l}\text { Identify perceptions and practices among health professionals in } \\
\text { Angola concerning intimate partner violence against women. }\end{array}$ & $\begin{array}{l}\text { Qualitative/cross- } \\
\text { sectional study }\end{array}$ & $\begin{array}{l}13 \text { professionals at three } \\
\text { hospitals }\end{array}$ & $\begin{array}{l}\text { Semi-structured } \\
\text { questionnaire }\end{array}$ \\
\hline $\begin{array}{c}\text { Gomes \& } \\
\text { Erdmann (12) }\end{array}$ & $\begin{array}{l}\text { Construct a theoretical matrix based on the meanings of interaction } \\
\text { and action experienced by professionals regarding nursing care } \\
\text { practices and the health of women in situations of conjugal } \\
\text { violence, all within the ambit of the family health strategy. }\end{array}$ & $\begin{array}{l}\text { Qualitative/cross- } \\
\text { sectional study }\end{array}$ & $\begin{array}{l}52 \text { professionals working } \\
\text { in family health teams }\end{array}$ & $\begin{array}{l}\text { Semi-structured } \\
\text { questionnaire }\end{array}$ \\
\hline Leitão (2) & $\begin{array}{l}\text { Understand the trajectories that women go through between } \\
\text { entering and leaving relationships, in terms of intimate partner } \\
\text { violence (IPV), and identify the stages of the transition process. }\end{array}$ & $\begin{array}{l}\text { Qualitative/cross- } \\
\text { sectional study }\end{array}$ & 28 women ages $23-62$ & $\begin{array}{l}\text { Semi-structured } \\
\text { questionnaire }\end{array}$ \\
\hline $\begin{array}{l}\text { Costa \& Lopes } \\
\quad(19)\end{array}$ & $\begin{array}{l}\text { Identify and analyze the practice of health care professionals } \\
\text { regarding rural women who are victims of violence, doing so } \\
\text { from the perspective of comprehensive care in in cities located in } \\
\text { southern Rio Grande do Sul state. }\end{array}$ & $\begin{array}{l}\text { Qualitative/cross- } \\
\text { sectional study }\end{array}$ & $\begin{array}{l}43 \text { women providing } \\
\text { services to women } \\
\text { victims of violence }\end{array}$ & $\begin{array}{l}\text { Semi-structured } \\
\text { questionnaire }\end{array}$ \\
\hline $\begin{array}{l}\text { Trigueiro \& } \\
\text { Labronici (20) }\end{array}$ & Identify risk factors that trigger domestic violence. & $\begin{array}{l}\text { Qualitative/cross- } \\
\text { sectional study }\end{array}$ & $\begin{array}{l}8 \text { women victims of } \\
\text { domestic violence }\end{array}$ & $\begin{array}{l}\text { Semi-structured } \\
\text { questionnaire }\end{array}$ \\
\hline Netto et al. (21) & $\begin{array}{l}\text { Analyze the consequences of intimate partner violence, from the } \\
\text { perspective of women, as an intervention proposal for nurses in } \\
\text { health care. }\end{array}$ & $\begin{array}{l}\text { Qualitative/cross- } \\
\text { sectional study }\end{array}$ & $\begin{array}{l}16 \text { women who reported } \\
\text { violence on the part of a } \\
\text { companion }\end{array}$ & $\begin{array}{l}\text { Semi-structured } \\
\text { questionnaire }\end{array}$ \\
\hline Silva et al. (22) & $\begin{array}{l}\text { Analyze limiting and potentializing situations during the assistance } \\
\text { provided by family health teams to women in situations of violence. }\end{array}$ & $\begin{array}{l}\text { Qualitative/cross- } \\
\text { sectional study }\end{array}$ & $\begin{array}{l}13 \text { women who reported } \\
\text { companion violence }\end{array}$ & $\begin{array}{l}\text { Semi-structured } \\
\text { questionnaire }\end{array}$ \\
\hline Vieira et al. (23) & $\begin{array}{l}\text { Understand the "motives" of the woman who takes action to } \\
\text { denounce her situation of violence. }\end{array}$ & $\begin{array}{l}\text { Qualitative/cross- } \\
\text { sectional study }\end{array}$ & $\begin{array}{l}11 \text { women victims of } \\
\text { conjugal violence }\end{array}$ & $\begin{array}{l}\text { Semi-structured } \\
\text { questionnaire }\end{array}$ \\
\hline $\begin{array}{l}\text { Gomes et al. } \\
\quad(24)\end{array}$ & $\begin{array}{l}\text { Describe, based on the representations of women with a history } \\
\text { of undergoing conjugal violence, the elements that constitute the } \\
\text { social support network for confronting this health problem. }\end{array}$ & $\begin{array}{l}\text { Qualitative/cross- } \\
\text { sectional study }\end{array}$ & $\begin{array}{l}13 \text { women who reported } \\
\text { partner violence to police } \\
\text { at the station }\end{array}$ & Interview \\
\hline $\begin{array}{l}\text { Svavarsdottir } \\
\text { \& Orlygsdottir } \\
\quad(14)\end{array}$ & $\begin{array}{l}\text { Identify the incidence of violence against women seeking } \\
\text { healthcare services and evaluate the use of clinical guidelines to } \\
\text { identify interpersonal violence. }\end{array}$ & $\begin{array}{l}\text { Quantitative/cross- } \\
\text { sectional study }\end{array}$ & $\begin{array}{l}14 \text { nursing professional, } \\
10 \text { midwives and } 208 \\
\text { women }\end{array}$ & $\begin{array}{l}\text { Semi-structured } \\
\text { questionnaire }\end{array}$ \\
\hline $\begin{array}{l}\text { Viviescas- } \\
\text { Vargas et al. } \\
\quad(25)\end{array}$ & $\begin{array}{l}\text { Estimate the effective coverage of primary health care services } \\
\text { in the management of domestic violence against women in three } \\
\text { Mexican cities. }\end{array}$ & $\begin{array}{l}\text { Qualitative/cross- } \\
\text { sectional study }\end{array}$ & 545 women ages $18-70$ & Conflict Tactics Scale \\
\hline $\begin{array}{l}\text { Nasrabadi et } \\
\text { al. (3) }\end{array}$ & $\begin{array}{c}\text { Estimate the prevalence of any violence against women referring } \\
\text { to health centers and explore the factors associated with risk of } \\
\text { violence in Ahvaz, Iran. }\end{array}$ & $\begin{array}{l}\text { Quantitative/cross- } \\
\text { sectional study }\end{array}$ & $\begin{array}{l}68 \text { married women aged } \\
15-55 \text { years }\end{array}$ & $\begin{array}{l}\text { Structured } \\
\text { questionnaire }\end{array}$ \\
\hline $\begin{array}{l}\text { Taherkhani et } \\
\text { al (17) }\end{array}$ & $\begin{array}{c}\text { Understand the experience of Iranian victims of intimate partner } \\
\text { violence. }\end{array}$ & $\begin{array}{l}\text { Qualitative / cross- } \\
\text { sectional study }\end{array}$ & $\begin{array}{l}11 \text { married women ages } \\
\text { 22-72 }\end{array}$ & $\begin{array}{l}\text { Semi-structured } \\
\text { questionnaire }\end{array}$ \\
\hline Hajian (5) & $\begin{array}{l}\text { Estimate the prevalence of physical and mental violence } \\
\text { perpetrated by men against their intimate partners and assess the } \\
\text { factors associated with partner violence among women in Shroud } \\
\text { in the northeastern region of Iran in } 2010 .\end{array}$ & $\begin{array}{l}\text { Quantitative / cross- } \\
\text { sectional study }\end{array}$ & 600 married women & $\begin{array}{l}\text { Structured } \\
\text { questionnaire }\end{array}$ \\
\hline $\begin{array}{l}\text { Semagegn et } \\
\text { al. (26) }\end{array}$ & $\begin{array}{c}\text { Determine the magnitude of domestic violence and identify } \\
\text { its predictors among married women of reproductive age in } \\
\text { northwestern Ethiopia. }\end{array}$ & $\begin{array}{l}\text { Qualitative/cross- } \\
\text { sectional study }\end{array}$ & 682 married women & Focus group \\
\hline
\end{tabular}




\begin{tabular}{|c|c|c|c|c|}
\hline References & Aims & Theoretical reference & Subjects & $\begin{array}{l}\text { Instrument for data } \\
\text { collection }\end{array}$ \\
\hline Ali et al. (27) & $\begin{array}{l}\text { Explore women's percep-tions of the consequences of violence, its } \\
\text { adverse effects on health, and how women resist violence within } \\
\text { marital life in urban Pakistan. }\end{array}$ & $\begin{array}{l}\text { Qualitative/cross- } \\
\text { sectional study }\end{array}$ & 28 women & Focus group \\
\hline $\begin{array}{l}\text { Guruge et al. } \\
\qquad(18)\end{array}$ & $\begin{array}{l}\text { Examine women's experience with violence throughout their lives } \\
\text { and the presence of physical and mental health symptoms in a } \\
\text { sample of Iranian and Sri Lankan Tamil immigrants and refugee } \\
\text { women in Canada. }\end{array}$ & $\begin{array}{l}\text { Quantitative/cross- } \\
\text { sectional study }\end{array}$ & 60 women & $\begin{array}{c}\text { Structured } \\
\text { questionnaire }\end{array}$ \\
\hline Ali et al. (28) & $\begin{array}{l}\text { Investigate the prevalence of physical and sexual violence and } \\
\text { psychological abuse perpetrated by husbands against their wives, } \\
\text { and any associated sociodemographic risk factors. }\end{array}$ & $\begin{array}{l}\text { Quantitative/cross- } \\
\text { sectional study }\end{array}$ & $\begin{array}{l}759 \text { married women ages } \\
\qquad 25-60\end{array}$ & $\begin{array}{l}\text { Multi-country Study } \\
\text { on Women's Health } \\
\text { and Life Experiences } \\
\quad \text { Questionnaire }\end{array}$ \\
\hline $\begin{array}{l}\text { NETTO et al. } \\
\qquad(25)\end{array}$ & $\begin{array}{l}\text { Analyze social networks and types of support for women in } \\
\text { situations of violence perpetrated by an intimate partner. }\end{array}$ & $\begin{array}{l}\text { Qualitative and analytical } \\
\text { research }\end{array}$ & $\begin{array}{l}20 \text { women who } \\
\text { experienced partner } \\
\text { violence }\end{array}$ & $\begin{array}{l}\text { A semi-structured and } \\
\text { individual instrument } \\
\text { was used. }\end{array}$ \\
\hline
\end{tabular}

Source: Own elaboration.

The submission that many women adopt for cultural reasons is also identified as a triggering factor in the perpetuation of violence (26).

Most women omit the violence suffered because there is the hope the abuser's feelings will prevail, thereby overcoming the situation, and the apologies and promises he made will be genuine (2). This mutes the problem and results in a situation where the relationship is maintained, all of which complicates making a decision.

In an effort to break this situation, some women report their attacker, demonstrating an attitude of non-compliance with the isolated or successive acts of violence they have suffered. The complaint is characterized as a way to disclose their rejection of a situation that has become progressively unsustainable (26).

The review showed evidence that the school has no direct relationship to violence. However, it did show that women living in situations of violence while unmarried tend to continue being abused even after being married. What changes in this condition is the aggressor.

\section{Discussion}

There was a consensus among the authors of the study that the production of scientific knowledge on the subject of violence against women represents a guiding principle for health policy by applying science to the concerns of those who use health services and await humanized action in this universe of biopsychosocial needs.
When observing the list of feelings triggered in women who are victims of violence, one sees a gap in the image created by common thinking in the sense that women who are caught in this cycle are devoid of feelings and are happy to live this way.

Anger and anguish, which appeared in five studies (3, 5, 7, 29), imply that living in these conditions requires attention to a woman's emotional state, which is commonly overlooked. It is known that most of them neglect to get the health care they require, which means the act and the aggressor end up being subdued and the woman's real needs are neglected.

This silence on the part of the victim must be respected as a need to understand what has occurred and the need for emotional reorganization. However, it should not blind the health professional into believing the woman wanted to be raped.

The definition given by women with respect to violence as being "an experience permeated by great humiliation" reinforces this as a public health problem that requires important action, starting with the way women are treated when seeking services (13). The denial and lack of comprehensive care that often occur at the hands of unprepared professionals who do not know how to deal with their own values and beliefs on the subject can trigger many feelings that will have an impact on the meaning the raped woman will give this experience, especially when the situation at the local hospital is uncomfortable and embarrassing (25). This 
leads to anger, pain, shame and feelings of anguish and abandonment, among others.

Services provided in a highly technical way prevent a humanized approach, which seeks sensitive listening and a dialogue between the user and the professional in search of a closer relationship that results in trust for adequate care $(6,19)$. Empowering women victims of violence by their silence shows a lack of understanding of the conditions concerning their right to free will.

The reception they receive in dimensional spheres has proven to be quite effective, since it is extremely important that a woman who is a victim of violence feels welcomed and understood in the face of her traumatic experience. It is necessary to create a relationship between the professional and the patient in order to discover other possible forms of violence experienced. It is noticeably easier to approach these women when trust is established (24).

Recognition of disorganization in customer service is evidenced as one of the impediments to providing assistance, as is the difficulty in identifying and treating the silence displayed by victims during the consultation, which requires further evaluation to confirm any suspicion (13).

The use of counseling, and the implementation of strategies and prevention for these abused women guarantees better care, thus allowing their quality of life to benefit. It is possible to emphasize that women who suffer physical or verbal violence feel the need to expose their feelings and it is in this context that health professionals should seek improvements in the way these victims are received (1). It is essential that these professionals use caution, not only when observing the complaints presented by the patient, but also in terms of detecting the signs and symptoms displayed during the service that is provided $(6,19)$.

As the initial treatment afforded to these victims commonly occurs in primary care services, these are clearly potential, local instances for identifying cases of violence, especially of the domestic variety, because women suffering from this type of violence seek health services more often (29).
The nurse needs to provide holistic care in order to support a woman who is a victim of aggression. This implies knowing how to deal with the patient and, after reception, trying to understand what has happened to her. The woman should be advised to denounce her aggressor or to seek help from institutions that also deal with women who have experienced or gone through situations like the one she has endured (13).

Activities such as group meetings where women have an opportunity to report their experiences and to share their stories can be used as a time to rethink solutions to their problems. They also offer an opportunity to start a new life in society (24).

\section{Conclusion}

The violence women routinely face disrupts their biopsychosocial appearance and has consequences that last for a long time. The results obtained in this study reveal the indispensability of hosting, support, empathy, professional training for multidisciplinary teams or individual professionals, and a willingness to help women who are affected by violence, regardless of how that assistance is rendered or of the form it takes.

Understanding the biopsychosocial aspects of abused women has yet to receive much attention from researchers, but was explored to some degree during the search for articles for this review.

This study shows the fragility of the assistance being provided to women who are victims of violence. The analysis of the studies selected here demonstrates that not all health professionals who are confronted with these situations are prepared to approach them correctly or know how to direct these victims towards the most appropriate form of behavior in response to violence.

The need to expand the knowledge of health professionals who work directly with these situations is a point to be considered.

There is also the need to understand the magnitude of the difficulty of breaking this cycle of violence and the socio-demographic situations in which women are inserted that have a direct effect on their choices. 


\section{References}

1. Krug EG et al., eds. World report on violence and health. Geneva, World Health Organization, 2002.

2. Leitão MNDC. Women survivors of intimate partner violence: the difficult transition to independence. Rev Esc Enferm USP. 2014;48:7-15. [cited 2015 jun 21]. Available from: http://www.ncbi.nlm.nih.gov/pubmed/25517829

3. Nikbakht Nasrabadi A, Hossein Abbasi N, Mehrdad N. The prevalence of violence against Iranian women and its related factors. Glob J Health Sci. 2015;7(3):37-45. [cited 2015 dec 10]. Available from: http://ovidsp.ovid.com/ovidweb.cgi?T $=\mathrm{JS} \& \mathrm{PAGE}=$ reference $\& \mathrm{D}=$ medl $\& N E W S=\mathrm{N} \& A N=25948434$

4. Netto LA, Moura MAV, Araujo CLF, Souza MHN, Silva GF. Social support networks for women in situations of violence by ann intimate partner. Enferm. 2017;26(2):e07120015. Available from: http://www.scielo.br/scielo.php?script=sci_ arttext\&pid=S0104-07072017000200333\&lng=en.

5. Hajian S, Vakilian K, Mirzaii Najm-abadi K, Hajian P, Jalalian M. Violence against women by their intimate partners in Shahroud in the northeastern region of Iran. Glob J Health Sci. 2014;6(3):117-30. [cited 2015 jun 21]. Available from: http://ovidsp.ovid.com/ovidweb.cgi?T=JS\&PAGE=reference\&D=medl\&NEWS=N\&AN=24762354

6. Trigueiro TH, Labronici LM. Chemical dependency as a risk factor for domestic violence against womem. Online Brazilian J Nurs. 2009;5(2):1-15.

7. Acosta DF, Lúcia V, Gomes DO, Dora A, Gomes GC. Violence against women commited by intimate partners :(in) visibility of the problem. Texto Context Enfermagem 2011;24(1):121-7.

8. Thomas SA, Oliver G, Bloom T, Gudehus S, Sherman J, Harris R. Intimate partner violence: enhancing vigilance of screening, treatment, and referral in the primary care setting. West J Nurs Res. 2016;38(10):1379-80. [cited 2016 jun 05]. Available from: https://www.ncbi.nlm.nih.gov/pubmed/27655086.

9. Brasil. Lei n.o 11.340 de 7 de agosto de 2006. Dispõe sobre a criação dos Juizados de Violência Doméstica e Familiar contra a Mulher; altera o Código de Processo Penal, o Código Penal e a Lei de Execução Penal; e dá outras providências. Brasil; 2006.

10. Kalokhe A. Domestic violence against women in India: A systematic review of a decade of quantitative studies. Glob Public Health. 2016;2(1):1-16. [cited 2016 jun 05]. Available from: http:// www.ncbi.nlm.nih.gov/pubmed/26886155.

11. Pan American Health Organization; Centers for Disease Control and Prevention. Violence against women in Latin America and the Caribbean: A comparative analysis of population-based data from 12 countries. Washington, DC: PAHO; 2012. [cited 2015 jun 21]. Available from: http://www1.paho.org/hq/dmdocuments/violence-against-women-lac.pdf.

12. Gomes NP, Erdmann AL. Conjugal violence in the perspective of "family health strategy" professionals: A public health problem and the need to provide care for the women. Rev Lat-Am Enfermagem. 2014;22(1):76-84. [cited 2015 jun 21]. Available from: http://www.scielo.br/scielo.php?script=sci_arttext\&pid=S0104-11692014000100076\&lng=en\&nrm=is o\&tlng=en

13. Nascimento E de FGA, Ribeiro AP, Souza ER de. Perceptions and practices of Angolan health care professionals concerning intimate partner violence against women. Cad Saúde Pública. 2014;30(6):1-10.

14. Svavarsdottir EK, Orlygsdottir B. Identifying abuse among women: Use of clinical guidelines by nurses and midwives. J Adv Nurs. 2009;65(4):779-88. [cited 2015 jun 21]. Available from: http://www.ncbi.nlm.nih.gov/pubmed/19183236

15. Moher D, Liberati A, Tetzlaff J AD. Preferred reporting items for systematic reviews and meta-analyses: The PRISMA Statement. Ann Intern Med. 2009;151(4):264-70.

16. Fleming PS, Koletsi D PNB. PRISMA: Are systematic reviewers focusing on PRISMA and ignoring other guidelines? PLoS One. 2009;9(5):1-7.

17. Taherkhani S, Negarandeh R, Simbar M, Ahmadi F. Iranian women's experiences with intimate partner violence : a qualitative study. Heal Promot Perspect. 2014;4(2):230-9. 
18. Guruge S, Roche B, Catallo C. Violence against women: An exploration of physical and mental health trends among immigrant and refugee women in Canada. Nurs Res Pract . 2012;2012:1-15. [cited 2015 jun 21]. Available from: http:// www.hindawi.com/journals/nrp/2012/434592/

19. da Costa MC, Lopes MJM. Elements of comprehensiveness in the professional health practices provided to rural women victims of violence. Rev Esc Enferm USP. 2012;46(5):1088-95.

20. Almeida MDL De, Luíza M, Segui H, Maftum MA, Labronici LM, Peres AM. Management tools used by nurses in decisionmaking within the hospital context. Texto Context Enferm. 2011;20:131-7.

21. Netto L de A, Moura MAV, Queiroz ABA, Tyrrell MAR, Bravo M del MP. Violence against womem and its consequences. Acta Paul Enferm. 2014;27(5):1-21. [cited 2015 jun 21]. Available from: http://newpsi.bvs-psi.org.br/tcc/152.pdf

22. Silva EB, Padoin SMM, Vianna LAC. Violence against women: the limits and potentialities of care practice. Acta paul. enferm. 2013 Dec;26(6):608-613. [cited 2015 jun 21]. Available from: http://www.scielo.br/scielo.php?script=sci_ arttext\&pid=S0103-21002013000600016\&lng=en. http://dx.doi.org/10.1590/S0103-21002013000600016.

23. Vieira LB, De Padoin SMM, De Oliveira IES, De Paula CC. Intencionalidades de mulheres que decidem denunciar situações de violência. ACTA Paul Enferm. 2012;25(3):423-9.

24. Gomes NP, Diniz NMF, Reis LA dos, Erdmann AL. The social network for confronting conjugal violence: representations of women who experience this health Issue. Texto Context Enferm. 2015;24(2):316-24.

25. Viviescas-Vargas DP, Idrovo AJ, Lopez-Lopez E, Uicab-Pool G, Herrera-Trujillo M, Balam-Gomez M, et al. Cobertura efectiva del manejo de la violencia contra mujeres en municipios mexicanos. Rev da Esc Enferm da USP. 2013;47(4):781-7. [cited 2015 jun 21]. Available from: http://www.scielo.br/scielo.php?script=sci_arttext\&pid=S0080-62342013000400781\&ln $\mathrm{g}=\mathrm{es} \& \mathrm{nrm}=\mathrm{iso} \& \operatorname{tlng}=\mathrm{en}$

26. Semahegn A, Belachew T, Abdulahi M. Domestic violence and its predictors among married women in reproductive age in Fagitalekoma Woreda, Awi zone, Amhara regional state, North Western Ethiopia. Reprod Health. 2013;10:63. [cited 2015 jun 21]. Available from: /pmc/articles/PMC3879008/?report=abstract

27. Ali TS, Krantz G, Mogren I. Violence permeating daily life: A qualitative study investigating perspectives on violence among women in Karachi, Pakistan. Int J Womens Health. 2012;4:577-85.

28. Ali TS, Asad N, Mogren I, Krantz G. Intimate partner violence in urban Pakistan: Prevalence, frequency, and risk factors. Int J Womens Health. 2011;3:105-15.

29. Okabe I, Fonseca RMGS da. Woman abuse: Contributions and shortcomings of the information system. Rev da Esc Enferm. 2009;43(2):453-8. 